JURNALYOGA DAN KESEHATAN

JURUSAN YOGA KESEHATAN

FAKULTAS BRAHMA WIDYA

IHDN DENPASAR
Vol. 3 No. 2 September 2020

ISSN : 2621-0185 (Cetak)

ISSN : 2722-9440 (Online)

http://ejournal.ihdn.ac.id/index.php/jyk

\title{
Makanan Sattvika dan Pengaruhnya Terhadap Kesehatan dan Karakter
}

\author{
Ayu Veronika Somawati ${ }^{1}$; Komang Surya Adnyana ${ }^{2}$ \\ Sekolah Tinggi Agama Hindu Negeri Mpu Kuturan Singaraja \\ email : ayuvero90@gmail.com ${ }^{1}$, suryakomank16@gmail.com ${ }^{2}$
}

Diterima tanggal 30 Juli 2020, diseleksi tanggal 15 Agustus 2020, dan disetujui tanggal 28 Agustus 2020

\section{ABSTRACT}

Being born as a human is a virtue in Hinduism, because among all living things only humans are gifted with the ability to think and distinguish good and bad deeds, and can help themselves from repeated births and deaths towards the ultimate goal of Hinduism. itself namely "Moksartham Jagadhita ya ca iti dharma". Because the primacy of birth as a human being, of course this opportunity must be very grateful and utilized as well as possible. One way that humans can do as a form of gratitude to Ida Sang Hyang Widhi Wasa for birth as a human being is to maintain the healthy body. With a healthy and wellmaintained body, surely a person will be able to work at maximum capacity Eating is not an activity to put food into the mouth carelessly and not measured. Eating in question is how a person is able to maintain the intake of food that enters his body properly and correctly so that what is eaten can function optimally for the health of the body. Judging from the science of nutrition, of course this will be associated with intake of carbohydrates, proteins, minerals, fats and others that enter the body. But when viewed from the teachings of Hinduism, regulating food patterns and intake of food that enters the body is also contained in Hindu religious literature, one of which is contained in the Bhagavad-gita a scriptures. And after further study, it can also be understood that what is eaten will ultimately affect one's mindset and character. By using descriptive methods, this paper will examine good food for body health (sattvika food) and its effect on someone's character.

Keywords : sattvika food, health, character

\section{ABSTRAK}

Terlahir sebagai manusia merupakan suatu keutamaan di dalam ajaran agama Hindu, karena diantara semua makhluk hidup hanya manusialah yang dikaruniai kemampuan untuk berpikir dan membedakan perbuatan baik-buruk, serta dapat menolong dirinya sendiri dari kelahiran dan kematian yang berulang-ulang menuju tujuan akhir agama Hindu itu sendiri yakni "Moksartham jagadhita ya ca iti dharma". Begitu utama kelahiran sebagai manusia, tentu kesempatan ini harus sangat disyukuri dan dimanfaatkan dengan sebaik-baiknya. Salah satu cara yang dapat dilakukan manusia sebagai bentuk rasa syukur kepada Ida Sang Hyang Widhi Wasa atas kelahiran sebagai manusia ini adalah dengan menjaga dan memelihara kesehatan tubuh. Makan yang dimaksud adalah bagaimana seseorang mampu menjaga asupan makanan yang masuk ke dalam tubuhnya secara baik dan benar sehingga apa yang dimakan dapat berfungsi maksimal bagi kesehatan tubuh. Ditinjau dari ilmu gizi, tentu hal ini akan dikaitkan dengan asupan karbohidrat, protein, mineral, lemak dan lain-lain yang masuk ke dalam tubuh. Tetapi apabila dikaji dari segi ajaran agama Hindu, ternyata mengatur pola makanan dan asupan makanan yang masuk ke dalam tubuh juga termuat di dalam literature agama Hindu, salah satunya yaitu termuat di dalam kitab suci Bhagavad-gìtā. Dan setelah dikaji lebih jauh lagi, dapat dipahami juga bahwa apa yang dimakan pada akhirnya akan mempengaruhi pola pikir serta karakter seseorang. Dengan menggunakan metode deskriptif, tulisan ini akan mengkaji mengenai makanan yang baik untuk kesehatan tubuh (makanan sattvika) serta pengaruhnya terhadap karakter seseorang.

Kata kunci : makanan sattvika, kesehatan, karakter 


\section{PENDAHULUAN}

Makanan adalah salah satu kebutuhan primer dari kehidupan manusia di dunia ini dan kebutuhan pokok bagi makhluk hidup untuk bertahan dan hidup. Tanpa adanya makanan, manusia tidak dapat bertahan hidup, karena manusia menempati urutan teratas dalam rantai makanan. Makanan merupakan sebuah kebutuhan mendasar manusia untuk melangsungkan hidup dan sebagai sumber energi untuk menjalankan aktivitas dalam kehidupan sehari-hari.

Pada dasarnya bahan makanan mengandung beberapa unsur atau senyawa seperti air, karbohidrat, protein, lemak, vitamin, dan lain-lain. Setiap makhluk hidup akan sulit dalam mengerjakan aktivitas sehari-harinya jika tidak mendapatkan makanan, dimana makanan dapat membantu manusia dalam mendapatkan energi, membantu pertumbuhan badan dan otak. Memakan makanan yang bergizi akan membantu pertumbuhan manusia, baik otak maupun badan. Setiap makanan mempunyai kandungan gizi yang berbeda. Protein, karbohidrat, dan lemak adalah salah satu contoh gizi yang akan didapatkan dari makanan.

Makanan yang dibutuhkan manusia biasanya dibuat melalui sumber hewan dan tumbuhan. Terkadang beberapa orang di dunia menolak untuk memakan makanan dari hewan seperti, daging, telur dan lain-lain. Mereka yang memilih untuk tidak mengkonsumsi daging dan sejenisnya disebut vegetarian yaitu mereka yang menjalani pola makan dengan hanya mengonsumsi makanan dari tumbuh-tumbuhan seperti gandum, kacang polong, biji-bijian, kacang-kacangan, jamur, ragi, buah-buahan, dan sayuran.

Memilih makanan yang tepat untuk dikonsumsi merupakan hal yang penting untuk diperhatikan mengingat pentingnya asupan yang tepat demi kesehatan tubuh manusia itu sendiri. Dengan tubuh yang sehat, akan sangat mempengaruhi kekuatan dan pikiran seseorang. Hal ini sejalan dengan pendapat dari Murphy (2011: 2) yang menyatakan bahwa kesehatan yang baik melipatgandakan efisiensi serta kekuatan setiap fungsi dan daya pikir manusia. Dengan adanya, kita dapat berpikir dengan baik, meningkatkan penilaian, meningkatkan energi, serta menyegarkan setiap sel dalam setiap jaringan tubuh. sebaliknya, otak yang lelah dan kalut tidak mampu melakukan pekerjaan dengan baik, berpikir dengan jernih, atau membuat rencana dengan efektif. Tubuh yang lelah karena kebiasaan-kebiasaan buruk -termasuk kurang tidur dan rekreasitidak dapat melakukan pekerjaan dengan baik.

Pengetahuan tentang makanan yang baik untuk kesehatan, pikiran dan karakter manusia tidak hanya didominasi oleh pengetahuan dari golongan ilmu-ilmu eksakta, karena di dalam ajaran agama Hindu pun terdapat pengetahuan mengenai makanan yang baik dikonsumsi oleh tubuh, salah satunya yang termuat di dalam pustaka suci Bhagavad-gìtā. Tulisan ini akan 
membahas mengenai makanan khususnya yang bersifat sattvika serta pengaruhnya terhadap kesehatan dan karakter orang yang mengkonsumsinya.

\section{PEMBAHASAN}

\subsection{Makanan dan Fungsinya untuk Tubuh}

Makanan merupakan sumber energi bagi semua makhluk hidup yang ada di dunia ini, tanpa kecuali manusia pun sangat membutuhkan makanan untuk tubuh agar dapat melakukan berbagai jenis aktivitas. Makanan dapat memberikan dampak yang cukup besar terhadap ketahanan dan kondisi tubuh pada manusia, makanan akan di proses dan diserap sari-sari makanannya di dalam tubuh untuk di bakar dan diedarkan keseluruh bagian tubuh sesuai dengan fungsinya. Makanan dapat mempengaruhi perkembangan sel, jaringan serta organ-organ tubuh manusia, maka jika tubuh manusia kemasukan bahan makanan yang mengandung toksin maka tubuh akan bereaksi serta memicu kerusakan pada bagian tubuh tertentu.

Disadari atau tidak, tanpa makanan tubuh manusia tidak akan bisa bekerja dengan baik serta tidak akan berkembang dan tumbuh dengan sempurna. Makanan mengandung asupan bahan yang dibutuhkan oleh tubuh. Namun terkadang kesadaran masyarakat akan pentingnya makanan sehat itu jarang dihiraukan. Hal ini terjadi dikarenakan tingkat kesadaran masyarakat yang kurang serta kebutuhan akan efisiensi waktu dan factor ekonomi yang menyebabkan masyarakat lebih memilih makanan instan dan murah.

Masyarakat tidak pernah menyadari bahwa makanan instan, makanan yang mengandung pengawet dan pemanis buatan yang saat ini sudah beredar banyak di masyarakat menyebabkan kesehatan menurun dan memicu penyakit-penyakit yang berbahaya. Belakangan ini sering muncul makanan berformalin, boraks, ayam tiren yang merupakan bukti bahwa ekonomi menyebabkan masyarakat apatis terhadap kesehatannya, sedangkan semua itu sangat berbahaya ketika di konsumsi oleh tubuh.

Jika makanan yang dikonsumsi tidak mengandung bahan-bahan yang diperlukan tubuh maka tubuh akan mengalami defisiensi seperti busug lapar, lupus, dll. Dan jika tubuh kelebihan makanan maka timbullah penyakit- penyakit seperti obesitas, diabetes, dll. Maka dari itu, makanan yang baik dikonsumsi untuk tubuh manusia adalah makanan yang sehat, bersih dan bergizi seimbang di dalam upaya menjaga kesehatan. Prima (2009: 8) di dalam bukunya menjelaskan bahwa fungsi dari makanan bukan semata-mata hanya untuk mengilangkan rasa lapar, melainkan untuk mendapatkan tenaga, karena pada dasarnya apa yang kita makan hendaknya harus memiliki lima fungsi utama, yaitu: (1) menyokong pertumbuhan tubuh; (2) sumber energi dan tenaga; (3) memelihara jaringan tubuh dan merevitalisasi sel-sel yang rusak; 
(4) mengatur metabolisme dan keseimbangan mineral di dalam cairan tubuh; serta (5) sebagai antioksidan dan antibodi tubuh. Selain itu harus memiliki lima unsur penting yang dibutuhkan oleh tubuh, yaitu: karbohidrat, protein, lemak, mineral, vitamin. Serta terdapat dua jenis zat non gizi yaitu air dan oksigen.

Selain itu, pada prinsipnya makanan yang kita makan berfungsi untuk melangsungkan kehidupan manusia. Kelangsungan hidup manusia tidak terlepas dari 3 hal yaitu bergerak, tumbuh dan mengatur aktivitas kehidupan. Pengelompokkan makanan digolongkan menjadi 3 yaitu (1) Zat Penghasil energi yaitu kelompok karbohidrat, lemak dan protein; (2) Zat pembangun yaitu kelompok protein, mineral dan vitamin; (3) Zat pengatur yaitu vitamin dan mineral (Dewi, A.B., dkk, 2013: 3).

Mengkonsumsi makanan yang akan kaya nutrisi dapat membuat tubuh tetap sehat, dan satu jenis makanan saja tidak akan mencukupi asupan dalam tubuh manusia. Maka pilihan makanan sehari-hari harus mencukupi karbohidrat dan produk padi-padian, buah-buahan, sayuran, produk susu serta daging, ikan atau makanan yang mengandung protein lainnya. Dimana Sumber daya manusia yang baik dan berkualitas dihasilkan dari tubuh yang sehat dengan mengkonsumsi makanan yang sehat dan bergizi. Makanan juga merupakan salah satu bagian yang penting untuk kesehatan manusia, karena dari makanan yang dikonsumsi tubuh manusia mendapatkan asupan-asupan gizi yang dibutuhkan untuk melakukan aktivitas (Sutriretna, 2013: 11-12). Dengan tidak menjaga asupan makanan yang masuk ke dalam tubuh, secara tidak sadar seseorang sedang merusak tubuhnya sendiri. Nelson (2001: 55) menyatakan bahwa mereka yang tidak bijaksana dalam hal makan berarti sedang melakukan tindakan bunuh diri dengan memakai sendok dan garpu! Banyak dari kebiasaan makan kita dimulai sejak muda, dan menjadi sukar untuk diubah. Alangkah jauh lebih baik kalau orang tua mendidik anak-anak mereka sejak balita dalam hal penggunaan garam, makanan gorengan, dan produk-produk gula yang sudah diolah secara sedikit-sedikit.

\subsection{Makanan dalam ajaran Agama Hindu}

Makan dan makanan memang tidak dapat dipisahkan dari kehidupan sehari-hari manusia. Gizi dari makanan yang dimakan atau dikonsumsi oleh seseorang merupakan sumber energi yang berguna untuk melaksanakan aktivitas sehari-hari. Memilih makanan yang tepat merupakan kunci terbaik agar makanan yang masuk ke dalam tubuh berguna bagi diri manusia itu sendiri sehingga bisa memberikan kesehatan jiwa dan raga.

Manusia sekarang dengan segala aktivitasnya yang padat, terkadang melupakan esensi dari makan dan makanan itu sendiri. Sekedar kenyang tanpa memperhatikan kandungan gizi 
yang masuk ke dalam tubuh terkadang menjadi pilihan dalam menjalani kegiatan sehari-hari. Bahkan tidak jarang orang hanya makan sekedarnya dan seadanya tanpa mempertimbangkan kebutuhan tubuh dengan tujuan untuk mengurangi pengeluaran sehari-hari. Seperti yang termuat pula di dalam buku yang ditulis oleh Darmayasa (1997: 5) yang menyatakan bahwa orang-orang berlomba mencari pekerjaan. Motif utamanya hanyalah sekedar untuk bisa makan. Tetapi setelah mendapatkan rejeki mereka tidak tahu "cara makan". Apa yang perlu/boleh dimakan dan apa yang tidak perlu tidak boleh dimakan, mereka tidak tahu sama sekali.

Ajaran agama Hindu mengajarkan bahwa bhuana agung (alam semesta) maupun bhuana alit (semua makhluk hidup, termasuk manusia itu sendiri) terdiri dari 2 (dua) unsur penciptaan yakni Purușa (unsur kejiwaan) serta Prakrti (unsur kebendaan). Kedua hal ini tidak dapat dipisahkan satu sama lain. Bagaimana tubuh bisa bekerja tanpa adanya unsur kejiwaan yang menghidupinya, dan begitu pula sebaliknya. Oleh karena itu, tubuh juga memiliki posisi yang penting di dalam usaha untuk mencapai tujuan akhir dari agama Hindu itu sendiri yakni "Moksartham Jagadhita ya ca iti dharma", yakni mencapai kesejahteraan dunia dan kebebasan abadi yang berdasarkan dharma atau kebenaran. Aryadharma (2019: 234) di dalam bukunya juga menguraikan bahwa Vedānta menguraikan tentang komposisi tubuh manusia, dimana atman merupakan inti dari keperibadian, atman membuat tubuh hidup, mampu memahami dan bertindak. Atman sebagai keperibadian sejati dibungkus dengan lima lapisan yang dikenal dengan Panca Maya Kosha. Setiap lapisan ini akan saling mempengaruhi dan setiap lapisan ini harus dipahami sehingga manusia mampu terbangun menjadi superhuman.

Ajaran Vedānta menguraikan bahwa tubuh merupakan lapisan yang menyelimuti inti hidup manusia (atman) itu sendiri. Tubuh sendiri bukanlah semata-mata "kubur" bagi jiwa itu sendiri. Tubuh merupakan sarana untuk menyatukan kembali atman kepada Brahman. Dewi (2019) mengungkapkan bahwa serupa dengan Yoga, aliran Vedānta juga tidak absolut memandang tubuh sebagai kendala untuk mencapai moksa, sebaliknya, tubuh adalah harapan untuk mencapai pembebasan. Ditekankan juga oleh Aryadharma (2005: 23) bahwa badan adalah tempat bersemayamnya Sang Pencitpa (Brahma) sehingga disebut sebagai Brahma-pura atau Kuil Tuhan.

Melihat pentingnya posisi tubuh di dalam ajaran agama Hindu, tentu seseorang harus sangat memperhatikan kesehatan tubuhnya sebagai bagian dari ungkapan rasa syukur kepada Ida Sang Hyang Widhi Wasa atas karunia dan kesempatannya untuk dapat terlahir sebagai manusia. Salah satu cara yang dapat dilakukan manusia untuk menjaga kesehatan tubuhnya yakni dengan memperhatikan jenis makanan yang masuk ke dalam tubuh, apakah makanan tersebut baik atau tidak bagi tubuh itu sendiri. Di dalam ajaran agama Hindu, terdapat 3 jenis makanan, yakni 
makanan yang disukai oleh mereka yang berada dalam sifat kebaikan (makanan yang bersifat sattvika); makanan yang disukai oleh orang-orang yang berada dalam sifat kenafsuan (makanan yang bersifat rajasika); serta makanan yang disukai oleh mereka yang berada di dalam sifat kegelapan (makanan yang bersifat tamasika.

Agama Hindu mengajarkan bahwa sebelum makan, hendaknya makanan yang dibuat dipersembahkan terlebih dahulu karena makanan yang sudah dipersembahkan memberikan dampak positif bagi tubuh dan dapat membebaskan diri dari dosa. Makanan yang sudah dipersembahkan serta didoakan terlebih dahulu, memiliki vibrasi positif dan tentu saja vibrasi tersebut akan mempengaruhi orang yang memakannya. Hal inilah yang menjadi landasan sebaiknya prasadham atau lungsuran dinikmati setelah dipersembahkan. Prasadham atau lungsuran merupakan salah satu sarana untuk mencapai tujuan tertinggi yang kekal abadi.

Makan bukanlah suatu kegiatan yang dilakukan hanya sekedar untuk memenuhi kebutuhan hidup. Lebih dari itu, di dalam ajaran agama Hindu makan juga merupakan suatu bentuk yajña atau korban suci kepada Ida Sang Hyang Widhi Wasa. Dengan mengkonsumsi makanan yang baik dan sehat, tentu secara tidak langsung pula telah mempersembahkan yang terbaik kepada Tuhan. Tuhan itu sendiri bersemayam di dalam semua makhluk ciptaannya sebagai vaiśhvānara, yang berarti “api pencernaan”, yang dinyalakan oleh kekuatan Tuhan. Di dalam Brihadāranyak Upaniṣhad, dinyatakan sebagai berikut :

ayam agnir vaiśhvānaro yo 'yam antaḥ puruṣhe

yenedam annam achyate (5.9.1)

Terjemahan :

Tuhan adalah api di dalam perut yang memungkinkan makhluk hidup untuk mencerna makanan.

Empat jenis makanan (Chaturvidham) yang dimaksud termuat di dalam kutipan berikut : "Chaturvidham means four types and annam means food. Food is categorized into four types: 1. Bhojya - Foods that are chewed, such as bread, chapatti, etc. 2. Peya-These are mostly liquid or semi-solid foods which we have to swallow or drink, such as milk, juice, etc. 3. Kośhya Foods that are sucked, such as sugarcane. 4. Lehya - This includes foods that are licked, such as honey, etc" (Mukananda, 2014).

Berdasarkan kutipan sloka di atas, dapat dipahami bahwa Tuhan ada dimana-mana, termasuk juga bersemayam di dalam tubuh setiap makhluk. Oleh karena itu, mengkonsumsi makanan yang baik merupakan salah satu bentuk yajña atau persembahan kepada Tuhan itu sendiri. Dan dengan melakukan kegiatan persembahan, maka seseorang akan mencapai tujuan akhir hidupnya yakni Tuhan. seperti yang termuat di dalam kutipan pustaka suci Bhagavad-gìtā IV. 24 sebagai berikut : 
brahmārpañá̉ brahma havir

brahmāgnau brahmaña hutam

brahmaiva tena gantavyaím

brahma-karma-samādhinā

Terjemahan :

Kegiatan mempersembahkan adalah Tuhan, persembahan itu sendiri adalah Tuhan, menghaturkan persembahan oleh Tuhan ke Api Suci Tuhan pun adalah Tuhan, dan bagi mereka yang seluruh perbuatannya merasuk lelap di dalam persembahan kepada Tuhan Yang Maha esa, tujuan akhir mereka pun adalah Tuhan (Darmayasa, 2013: 323).

\subsection{Makanan Sattvika dan Pengaruhnya Terhadap Kesehatan dan Karakter}

Disadari atau tidak, makanan yang dikonsumsi akan sangat mempengaruhi kesehatan tubuh orang yang mengkonsumsinya. Oleh karena itu, untuk menjaga kesehatan serta stamina tubuh hendaknya makanan yang dikonsumsi diarahkan kepada makanan-makanan yang baik dan sehat. Hal ini dilakukan agar makanan yang masuk ke tubuh benar-benar berguna untuk tubuh serta membawa kebaikan. Dengan tubuh yang sehat, tentu seseorang akan dapat beraktivitas dengan baik dan optimal. Menghindari makanan yang hanya sekedar memberikan kenikmatan semata tanpa memiliki fungsi yang baik bagi tubuh merupakan salah satu langkah yang bijak untuk dilakukan. Darmayasa (1997: 4-5) di dalam bukunya mengungkapkan bahwa kita makan hendaknya bukan untuk kenikmatan lidah, tetapi mestilah dengan kesadaran untuk memelihara tubuh agar bisa dipakai untuk melakukan pelayanan kepada Tuhan Yang Mahaesa, bangsa dan negara. Makanan ini harus mengandung unsur-unsur yang dibutuhkan untuk pemeliharaan tubuh. Unsur-unsur yang diperlukan tubuh dari makanan pada pokoknya adalah protein, karbohidrat, lemak dan garam.

Pikiran yang baik mengarahkan seseorang menjadi bijaksana dan pada akhirnya dapat mencapai tujuan hidup itu sendiri yakni kebebasan. Seperti yang termuat di dalam kutipan berikut ini "Makanan sattvika sangat penting bagi kehidupan spiritual dan kesehatan. Menyantap makanan sattvika dapat memurnikan pikiran dan menyembuhkan badan dengan menyeimbangkan unsur-unsur di dalam tubuh, melepaskan racun dalam tubuh, dan memberi nutrisi yang diperlukan untuk memperkuat sistem kekebalan tubuh" (Arsa, 2007: 199). Dikuatkan juga dengan kutipan dari Suhardana (2010 : 35-36) yang mengatakan bahwa mengkonsumsi makanan yang bersifat sattvika memberikan efek yang lebih baik kepada pikiran daripada mengkonsumsi makanan rajasika atau tamasika. Para Rsi dan Brahmana pada jaman dahulu mengkonsumsi makanan sattvika untuk meningkatkan sifat sattwam pada dirinya.

Makanan khususnya di dalam ajaran agama Hindu tidak hanya mempengaruhi kesehatan orang yang mengkonsumsinya. Lebih dari itu. Makanan yang masuk ke dalam tubuh juga 
diyakini mempengaruhi kehidupan spiritual seseorang. Dengan tubuh yang sehat, tentu manusia dapat mengelola pikirannya dengan baik, sehingga terbentuk pula suatu kesadaran spiritual dan karakter yang baik. Jnana (2007: 98) di dalam bukunya juga menguraikan bahwa makanan sattvika adalah makanan yang sangat penting untuk kehidupan spiritual dan kesehatan kita. Memakan makanan sattvika adalah satu cara yang paling penting untuk memurnikan pikiran dan penyembuhan tubuh dengan menyeimbangkan ketiga dosha, mengeluarkan semua racun dalam tubuh, dan memberikan nutrisi yang dibutuhkan tubuh untuk menguatkan sistem kekebalan tubuh. Nala (2001: 97-98) di dalam bukunya juga mengatakan bahwa makanan sattvika merupakan makanan yang dapat menambah sifat bijaksana, sabar serta mampu menjaga keseimbangan unsur tri dosha dalam tubuh. Menurut ilmu Ayurweda, mengkonsumsi makanan sattvika dapat memperpanjang usia, menyucikan pikiran, menguatkan tubuh, menyehatkan tubuh, membuat bahagia, dan meningkatkan kualitas hidup. Dengan cara mengkonsumsi makanan sattvika disertai penyajiannya memuaskan panca indria, sehingga baik raga sarira maupun suksma sarira terpuaskan, dengan demikian kedua sarira ini dapat berfungsi secara optimal, menjadikan tubuh tetap svasthya (sehat).

Manusia lahir pada dasarnya dengan membawa 3 (tiga) sifat dasar yang disebut dengan Tri Guna, yaitu sattvam atau sifat kebaikan yang membentuk karakter manusia, rajas atau sifat nafsu manusia yang perlu dikendalikan, serta tamas atau sifat gelap yang perlu dimurnikan. Ketiga sifat dasar ini tidak mampu dihilangkan begitu saja dari dalam diri manusia, yang dapat dilakukan adalah mengendalikan sifat rajas dan tamas sehingga sifat sattvam dapat mendominasi diri seseorang. Dengan mengkonsumsi makanan yang bersifat sattvika, maka sifat sattvam yang ada di dalam diri manusia dapat disucikan serta dimunculkan untuk mendominasi diri manusia tersebut sehingga kebijaksanaan akan membentuk karakter orang yang mengkonsumsinya.

Makanan sattvika sangat penting bagi kehidupan spiritual dan kesehatan. Menyantap makanan sattvika sekaligus memurnikan pikiran dan menyembuhkan badan dengan menyeimbangkan kecenderungan biologis, melepaskan racun-racun dengan menyediakan segala substansi nutrisi yang diperlukan dan memperkuat system kekebalan tubuh ( $\mathrm{Ra}$ dan Jendra, 2007: 211). Oleh karena itu, menjaga asupan makanan dengan mengkonsumsi makanan yang bersifat sattvika sangatlah penting bagi kesehatan tubuh, kesehatan pikiran serta akan berpengaruh terhadap karakter seseorang. Murphy (2011: 5) di dalam bukunya juga menyatakan bahwa saat kita menyadari bahwa kesehatan yang baik melipatgandakan kekuatan atau inisiatif, meningkatkan kemampuan kreatif, membangkitkan antusiasme dan spontanitas, serta menguatkan kualitas penilaian dan cara mengambil keputusan, kita akan lebih teliti saat merawat tubuh. 


\section{PENUTUP}

Kelahiran sebagai manusia disebut sebagai kelahiran yang utama, oleh karena itu kesempatan ini harus sangat disyukuri dan dimanfaatkan dengan sebaik-baiknya. Salah satu cara yang dapat dilakukan manusia sebagai bentuk rasa syukur kepada Ida Sang Hyang Widhi Wasa adalah dengan mengatur pola makan agar tubuh yang dimiliki menjadi sehat dan dapar melakukan segala aktivitas dengan baik. Makanan merupakan salah satu kebutuhan primer dari kehidupan manusia di dunia ini dan kebutuhan pokok bagi makhluk hidup untuk bertahan dan hidup, termasuk manusia. Makanan juga merupakan salah satu bagian yang penting untuk kesehatan manusia, karena dari makanan yang dikonsumsi tubuh manusia mendapatkan asupanasupan gizi yang dibutuhkan untuk melakukan aktivitas. Pengetahuan mengenai asupan makanan yang baik untuk dikonsumsi oleh manusia tidak semata-mata dimiliki oleh ilmu-ilmu yang termasuk ke dalam ilmu eksakta. Di dalam ajaran agama Hindu melalui literaturnya, salah satunya yaitu pustaka suci Bhagavad-gìtā juga memuat tentang jenis-jenis makanan yakni makanan yang disukai oleh mereka yang berada dalam sifat kebaikan (makanan yang bersifat sattvika); makanan yang disukai oleh orang-orang yang berada dalam sifat kenafsuan (makanan yang bersifat rajasika); serta makanan yang disukai oleh mereka yang berada di dalam sifat kegelapan (makanan yang bersifat tamasika). Ajaran agama Hindu mengarahkan manusia untuk mengkonsumsi makanan yang bersifat sattvika.

\section{DAFTAR PUSTAKA}

Arsa, G. D. (2007). Kesehatan dan Meditasi Matahari Terbit. Surabaya: Paramita.

Aryadharma, N. K. (2005). Melahirkan Generasi Berkarakter Dewata Kiat Sukses Siswa Menurut Hindu. Surabaya: Paramitha.

Aryadharma, N. K. (2019). Vedantha dan Metode Pemahaman Filsafat Hindu. Surabaya: Paramitha.

Darmayasa. (1997). Ahimsa Dharma dan Vegetarian. Surabaya: Paramitha.

Darmayasa. (2013). Bhagavad-gita (Nyanyian Tuhan). Denpasar: Yayasan Dharma Sthapanam.

Dewi, A. B., Pujiastuti, N., \& Fajar, I. (2013). Ilmu Gizi untuk Praktisi Kesehatan. Yogyakarta: Graha Ilmu.

Jnana, S. (2007). Makanan Satvik dan Kesehatan. Surabaya: Paramitha.

Murphy, J. (2011). Rahasia Memaksimalkan Potensi lewat Kekuatan pikiran Bawah Sadar untuk Mendapatkan Kesehatan dan Vitalitas. Terjemaha : Nengah Krisnarini. Jakarta: Pt. Gramedia Pustaka Utama.

Nala, N. (2001). Ayurveda Ilmu Kedokteran Hindu I. Denpasar: Upada Sastra. 
Nelson, E. R. (2001). Delapan Obat Alami. Terjemahan Loddy J. Lintong. Bandung: Indonesia Publishing House.

Prima, S. W. (2009). Makanan Satvik dan Kesehatan. Surabaya: Paramitha.

ra, A., \& Jendra, I. W. (2007). Kesehatan dan Spiritual. Surabaya: Paramitha.

Suhardana, K. (2010). Ahimsa dan Vegetarian Jalan Menuju Kasih Sayang. Surabaya: Paramitha.

Sutriretna, N. (2013). Mengenal Makanan dan Kesehatan. Bandung: Pt Kiblat Buku Utama.

\section{Sumber Online :}

Bhagavad Gita The Song of God Commentary by Swami Mukundananda. Bhagavad Gita : Chapter 15, Verse 14. Diakses pada tanggal 25 Juli 2020, dari https://www.holybhagavad-gita.org/chapter/15/verse/14

Yayasan Padma Bhuana. Ayurveda. Diakses pada tanggal 25 Juli 2020, dari https://www.padmabhuana.com/ayurveda.html 